\title{
KAJIAN KONFLIK DALAM PENGADAAN TANAH UNTUK PEMBANGUNAN JALUR EVAKUASI TSUNAMI ALAI-BY PASS DI KOTA PADANG*
}

\author{
Hery Listyawati** dan Sulastriyono ${ }^{* * * *}$ \\ Departemen Hukum Agraria dan Hukum Adat, Fakultas Hukum, \\ Universitas Gadjah Mada, Yogyakarta \\ Jalan Sosio Yustisia Nomor 1 Bulaksumur, Sleman, D.I. Yogyakarta, 55281
}

\begin{abstract}
One of the problems in the area of land acquisition on tsunami evacuation construction Alai-by pass in Padang city is the time consuming taken by the government to take over the land rights of the society. The project had been done since 2003, but until now it has not completely accomplished which caused by a particular conflict between the land holders against the government in dealing with the land acquisition, like compensation. Therefore, this research studies factors which cause the conflict and efforts done by the parties to manage the conflict.
\end{abstract}

Keywords: land acquisition, conflict, compensation.

\section{Intisari}

Salah satu permasalahan terkait pengadaan tanah untuk pembangunan jalur evakuasi tsunami Alai-by Pass di Kota Padang yakni lamanya proses pengadaan tanah yang dialami pemerintah untuk mengambil alih hak atas tanah dari masyarakat. Proyek tersebut berlangsung sejak tahun 2003, namun hingga saat ini belum uga selesai. Hal ini disebabkan oleh munculnya konflik antara pemegang hak atas tanah dengan pemerintah terkait proses pengadaan tanah, termasuk mengenai ganti kerugian. Oleh karena itu, tulisan ini akan mengkaji faktor penyebab konflik dan upaya yang dilakukan para pihak untuk mengelola konflik.

Kata Kunci: pengadaan tanah, konflik, ganti kerugian.

\section{Pokok Muatan}

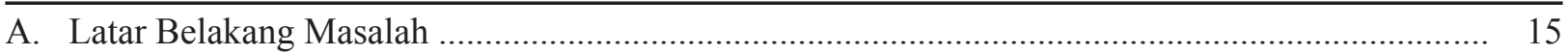

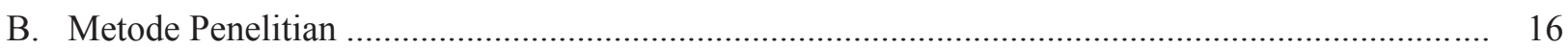

C. Hasil Penelitian dan Pembahasan ............................................................................................ 16

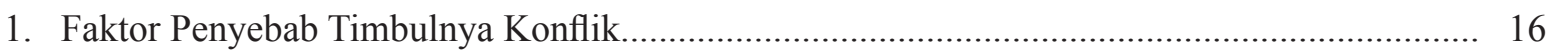

2. Upaya Para Pihak dalam Mengatasi Konflik........................................................................ 23

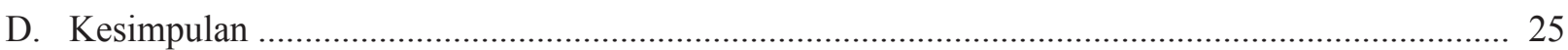

Hasil Penelitian Fakultas Hukum Universitas Gadjah Mada.

** Alamat korespondensi: liliso12@yahoo.com

**** Alamat korespondensi: sulastriyono@mail.ugm.ac.id 


\section{A. Latar Belakang Masalah}

Gempa yang terjadi sehari menjelang puasa dan pada hari pertama puasa tahun 2007 yang lalu itu, berpusat di Sipora/Pagai Kepulauan Mentawai dengan kekuatan 8,4 SR dan 7,9 SR adalah gempa terbesar yang melanda Kota Padang dan mengakibatkan kerusakan yang luar biasa. Sejak saat itu masyarakat Sumatra Barat umumnya dan Padang khususnya terus membangun kesiapan untuk mewaspadai bencana yang satu ini. Bahkan sebetulnya sejak gempa besar dan tsunami Aceh 26 Desember 2004, kewaspadaan itu sudah mulai dibangun. Dalam membangun kewaspadaan itu banyak yang telah dilakukan, terutama dalam menyadarkan masyarakat di wilayah ini, ternyata Indonesia rawan terhadap gempa dan juga berpotensi datangnya tsunami bagi daerah-daerah pesisir. ${ }^{1}$ Kewaspadaan ini ditindaklanjuti dengan pembangunan pelebaran Alai-by Pass.

Pembangunan jalan Alai-by Pass ini merupakan rangkaian kegiatan pembangunan Padang Bay City (BPC) yang merupakan mega proyek yang sangat besar. Tentu saja kegiatan ini akan sulit terwujud apabila semua komponen dan stake holders yang ada tidak memiliki pandangan dan visi yang sama dalam mendorong terealisasinya rencana ini. Rencana pembangunan PBC pada intinya mempunyai maksud dan tujuan mempercepat pertumbuhan pembangunan infrastruktur kota pada kawasan pesisir pantai Padang, dan menjadikan PBC sebagai salah satu "land mark" kota Padang yang merupakan pintu gerbang dan tujuan wisata Sumatera Barat. Hal ini diharapkan akan mampu menjadi lokomotif pergerakan ekonomi riil serta penyediaan lapangan kerja baru, selain sebagai salah satu upaya preventif penanganan resiko bencana gempa dan tsunami (vertical mitigation) bagi masyarakat pesisir pantai Padang.

Untuk pelebaran jalan Alai-by Pass ini perlu diadakan pengadaan tanah oleh pemerintah setempat, yang mencakup 2 (dua) kecamatan, yaitu Kecamatan Padang Utara dan Kecamatan Kuranji, dan mencakup 4 (empat) kelurahan, yaitu Kelurahan Alai Parak Kopi, Kelurahan Ampang, Kelurahan
Lubuk Lintah, Kelurahan Pasar Ambacang. Pembangunan jalan utama Alai-by Pass yang merupakan jalur evakuasi tsunami seharusnya sudah diselesaikan oleh Pemerintah Provinsi Sumatera Barat, tapi juga terbengkalai karena Pemerintah Kota Padang tidak kunjung tuntas membebaskan lahannya. ${ }^{2}$

Pembangunan pelebaran jalan Alai-by Pass menurut Peraturan Presiden Nomor 65 Tahun 2006 (Perpres No. 65 Tahun 2006) dan kini telah dicabut dengan Undang-Undang Nomor 2 Tahun 2012 tentang Pengadaan Tanah Untuk Kepentingan Umum, telah memenuhi syarat sesuai kategori kegiatan pembangunan untuk kepentingan umum. Meskipun demikian dalam menggunakan tanah yang sudah dilekati hak atas tanah, negara harus menghormati hak-hak dari pemegang hak tersebut. Tanah yang digunakan untuk pembangunan proyek ini berupa tanah masyarakat baik individu maupun komunal yang dikenal sebagai tanah ulayat.

Proses pengadaan tanah yang telah berlangsung sejak tahun 2003 sampai akhir tahun 2011 belum juga selesai disebabkan adanya konflik antara pihak yang memerlukan tanah (pemerintah) dengan pihak yang tanahnya dibebaskan (masyarakat). Gubernur Irwan Prayitno sudah menginstruksikan agar persoalan pembangunan jalur evakuasi Padang di kawasan Alai sampai ke jalan by-pass dilanjutkan saja meskipun masih ada 13 (tiga belas) titik masalah yang tidak kunjung tuntas. Bila sampai batas waktu akhir tahun anggaran masih tersisa lahan yang belum bisa dibebaskan, konsekuensinya akan ada beberapa penyempitan di jalur evakuasi itu. 13 (tiga belas) titik ini menjadi tanggung jawab Pemerintah Kota Padang. Upaya untuk menuntaskan persoalan dengan masyarakat ternyata sampai sekarang belum selesai, meskipun diantara pemilik tanah sudah pernah mendapatkan ganti kerugian. Dari kasus ini kelihatan kepada publik siapa saja sebenarnya yang tidak mau menyelesaikan jalur yang sangat penting bagi penyelamatan warga apabila memang terjadi tsunami. ${ }^{3}$

Berdasarkan uraian di atas dan ketentuanketentuan yang ada, maka penulis berkeinginan mengkaji permasalahan tersebut melalui penelitian

Gusti Ayu Gayatri, "Harus Perbanyak Simulasi Tsunami”, http://padangekspres.co.id/?news=berita\&id=50299, diakses 28 Desember 2009. Ibid.

Anonim, "Prinsip Keadilan adalah Kunci Soal Alay-by Pass", http://www.Padang Ekspress.co.id, diakses 1 Februari 2012. 
dengan judul "Kajian Konflik dalam Pengadaan Tanah untuk Pembangunan Jalur Evakuasi Tsunami Alay-by Pass di Kota Padang”. Berdasarkan latar belakang sebagaimana diuraikan di atas, permasalahan yang akan diteliti dalam penelitian ini adalah: Pertama, faktor-faktor apa sajakah yang menjadi penyebab timbulnya konflik dalam pengadaan tanah untuk pembangunan jalur evakuasi Tsunami AlaiBy pass di kota Padang? Kedua, bagaimanakah upaya yang dilakukan oleh para pihak yang berkonflik untuk menyelesaikan masalah tersebut?

\section{B. Metodologi Penelitian}

Penelitian ini bersifat deskriptif yaitu penelitian yang dilakukan untuk mengungkapkan atau menggambarkan keadaan-keadaan atau gejala-gejala yang ada di lapangan atau di dalam praktek. Data tersebut dianalisis dengan mengaitkan dan memadukannya dengan data sekunder. Penelitian ini mengambil sampel di Kecamatan Kuranji serta di 2 (dua) kelurahan, yaitu Kelurahan Ampang dan Kelurahan Lubuk Lintah. Pemilihan sampel menggunakan teknik purposive dengan pertimbangan bahwa di kecamatan tersebut dilaksanakan pembebasan tanah untuk pembuatan jalur evakuasi tsunami dan muncul konflik dalam membebaskan tanah ulayat. Responden yang dipilih adalah: (a) Sekretaris Kecamatan Kuranji; (b) Lurah Ampang; (c) Lurah Lubuk Lintah; (d) Pejabat Kantor Pemerintahan Kota Padang; (e) Pejabat Panitia Pengadaan Tanah Kota Padang; (f) Pejabat Dinas Perhubungan Provinsi Sumatra Utara; dan (g) Ketua KAN (Kerapatan Adat Nagari); dan (h) Para tetua adat lainnya.

\section{Hasil Penelitian dan Pembahasan}

\section{Faktor Penyebab Timbulnya Konflik}

\section{a) Faktor Internal dari Masyarakat}

1) Subyek Hak yang Tidak Jelas

Istilah "Konflik" secara etimologis berasal dari bahasa latin "con" yang berarti bersama, dan "fligere" yang be- rarti benturan atau tabrakan. ${ }^{4}$ Menurut Hakimul Ikhwan Affandi, konflik merupakan gejala yang tidak mungkin dihindari dalam masyarakat. ${ }^{5}$ Konflik adalah proses alami yang umum bagi semua masyarakat. ${ }^{6}$ Dengan demikian konflik dapat terjadi di dalam individu sendiri, antar pribadi, individu dengan kelompok, antar kelompok, antar organisatoris. ${ }^{7}$ Menurut keterangan sekretaris Camat Kuranji, permasalahan yang menyebabkan konflik timbulkketika ganti kerugian akan diberikan, terjadi kesulitan menentukan subyek haknya. Subyek hak penerima ganti kerugian ini ini tidak jelas karena banyak tanah-tanah yang belum disertipikatkan. Menurut Sjamsir Dt Perpatih dalam Kurnia Warman, pendaftaran tanah menimbulkan kecemasan akan hapusnya tanah pusaka tinggi. ${ }^{8}$ Tanah tersebut kebanyakan masih milik persekutuan hukum adat dalam kekerabatan yang dikenal dengan" tanah ulayat". Menurut Maria SW Sumardjono, keberadaan hak ulayat ditentukan berdasarkan 3 (tiga) kriteria yaitu: (1) adanya masyarakat hukum adat yang mempunyai ciri-ciri tertentu sebagai subyek hak ulayat; (2) adanya wilayah dengan batas-batas tertentu sebagai obyek hak ulayat; (3) adanya kewenangan masyarakat hukum adat yang melakukan tindakan. ${ }^{9}$ Kriteria ini sesuai dengan tanah yang digunakan proyek ini. Menurut Iman Sudiyat, rechtsgemeenschap adalah satu kesatuan masyarakat hukum yang mempunyai tata hukum sendiri, dan dapat melaksanakan hubungan hukum dalam lalu lintas hukum dengan sub-

Abu Rohmad, 2008, Paradigma Resolusi Konflik Agraria, Walisongo Press, Semarang, hlm. 10.

Hakimul Ikhwan Affandi, 2004, Akar Konflik Sepanjang Zaman, Elaborasi Pemikiran Ibnu Khaldun, Pustaka Pelajar, Yogyakarta, hlm. 135. P. Wehr, 1979, Conflict Regulation, CO. Westview Press, Boulder, hlm. 1-8.

Richard E. Walton, 1969, Interpersonal Peace-Making: Confrontation and Third-Party Consultation, Reading, Mass, Addision-Wesley, hlm. 2 .

Kurnia Warman, 2006, Ganggam Bauntuak Menjadi Hak Milik, Penyimpangan Konversi HAT di Sumatra Barat, Andalas University Press, Padang, hlm. 9. 
yek hukum lainnya, mempunyai kekayaan yang digunakan untuk kepentingan seluruh anggota masyarakat hukum tersebut. ${ }^{10}$ Tanah ulayat ini di bawah kekuasaan ninik-mamak. Akan tetapi tanah-tanah yang terkena proyek sudah didirikan rumah beserta tanam-tanaman serta benda-benda lain milik keponakan-keponakan, sehingga dalam hal ini sulit menentukan siapa yang berhak atas ganti kerugian tersebut. Beberapa kali sudah dilakukan musyawarah, akan tetapi musyawarah tersebut tidak membuahkan hasil yang maksimal. Jika ganti kerugian hanya diberikan kepada para kemenakan, maka ninik mamak merasa dirugikan. Demikian pula sebaliknya. Disini kemudian seolah-olah terjadi perubahan peran oleh para ninik-mamak, dari yang semula sebagai pe-nguasa dalam arti mempunyai kewenangan untuk mengatur peruntukan, penggunaan, persediaan dan pemeliharaan tanah (bersifat publik), menjadi pemilik (bersifat privat) manakala terjadi pembagian ganti kerugian. ${ }^{11}$

2) Obyek ganti kerugian tidak termasuk tanah tetapi hanya tanaman dan bangunan sehingga hanya pihak anggota kaum yang mempunyai bangunan dan tanaman saja yang mendapatkan ganti kerugian.

3) Jumlah ganti kerugian yang diterima oleh setiap anggota kaum berbeda tergantung pada sedikit atau banyaknya tanaman dan ba-ngunan yang terkena jalur pengadaan tanah untuk pembangunan sehingga ada kecemburuan dari para anggota kaum.

4) Sifat masyarakat yang relatif tidak disiplin, tingkat pendidikan yang rendah dan tempe-ramental, sehingga mengakibatkan musyawarah yang di- laksanakan di Kantor KAN tidak dapat berjalan lancar. Tidak disiplin ini misalnya tidak semua undangan dapat hadir pada setiap musyawarah. Sifat temperamental juga menyebabkan sulitnya tercapai kata sepakat, sehingga perlu musyawarah berkali-kali.

b) Faktor Internal dari Masyarakat

1) Ketidakmampuan pemerintah dalam mendekati masyarakat. Menurut keterangan Ketua KAN kecamatan Kuranji, akar konflik yang timbul dalam pengadaan tanah untuk pembangunan jalur evakuasi tsunami Alai-by Pass ini bukan berasal dari nilai nominal ganti kerugian, akan tetapi berakar dari ketidakmampuan pemerintah kota yang diwakili oleh Panitia Pengadaan Tanah dalam melakukan pendekatan terhadap masyarakat adat setempat. Ketidakmampuan pendekatan kepada masyarakat ini karena ketidakpahaman terhadap budaya masyarakat setempat. Dengan demikian mekanisme pelepasan tanah ulayat juga kurang diperhatikan sesuai nilai-nilai yang terkandung dalam masyarakat hukum adat setempat. Pada mulanya masyarakat adat setempat memandang tanah ulayat banyak mengandung nilai sosial kebersamaan dari pada nilai ekonomisnya, sehingga pengalamanpengalaman terdahulu, banyak tanahtanah ulayat yang digunakan untuk kepentingan umum seperti sekolah, masjid, jalan raya, dengan mekanisme "suka rela", sehingga masyarakat persekutuan adat merelakan begitu saja tanahnya tanpa menuntut ganti kerugian. Pemikiran ini didasari akan fungsi dan manfaat dari pembangunan itu terhadap seluruh lapisan masyarakat. Akan tetapi dalam pengadaan tanah ini kemudian

\footnotetext{
Maria SW Sumardjono, 2007, Kebijakan Pertanahan, Antara Regulasi dan Implementasi, Penerbit Buku Kompas, Jakarta, hlm. 57. Iman Sudiyat, 1981, Hukum Adat Sketsa Asas, Liberty, Yogyakarta, hlm. 7.

Wawancara dengan Sekretaris Camat Kuranji tanggal 9 April 2012.
} 
diberikan ganti kerugian berupa uang, sehingga merubah mind set yang semula gotong-royong menjadi materialistis. Ketidakpahaman terhadap budaya setempat juga mengakibatkan ketidakmampuan dalam mengelola konflik (conflict management) sehingga memerlukan waktu lama dalam penyelesaiannya. Sifat kedermawanan masyarakat hukum adat setempat juga disalahgunakan oleh pemerintah. Karena menurut peraturan perundangan tentang pengadaan tanah pada waktu itu yaitu mulai Perpres No. 36 Tahun 2005 yang kemudian disempurnakan menjadi Perpres No. 65 Tahun 2006, dan kemudian diganti dengan Undang-Undang Nomor 2 Tahun 2012, seharusnya ganti kerugian juga diberikan kepada pemilik tanah dalam hal ini seluruh persekutuan hukum adat, tidak hanya kepada para keponakan yang mendirikan bangunan dan tanaman yang ada di atas tanah persekutuan. ${ }^{12}$ Ganti kerugian kepada masyarakat hukum adat tersebut atas tanahnya seharus-nya berupa recognitie sesuai dengan kesepakatan dengan ketua KAN beserta para tetua adat dan anggota persekutuan hukum adat.

2) Penentuan ganti kerugian yang terke- san sepihak. Adanya SK Walikota Padang tentang penetapan harga ganti-rugi bangunan dan tanaman dalam setiap tahapan pengadaan tanah mengindikasikan harga yang ditetapkan sepihak, dalam arti penawaran datang pertama kali dari pihak pemerintah, bukan berdasarkan permintaan yang diajukan warga. Berdasarkan hasil penelitian pustaka $^{13}$ dan berdasarkan wawancara dengan Yoga, Pejabat Pemkot Padang, ${ }^{14}$ pengadaan tanah untuk pelebaran jalan Alai-by pass dilaksanakan dalam 3 (tiga) tahap, yaitu:

\section{(1) Tahap Pertama pada Tahun 2003}

Berdasarkan hasil kesepakatan antara masyarakat dengan Pantia Pengadaan Tanah Kota Padang dan Tim Pembantu disepakati bahwa bentuk ganti kerugian yang diberikan berupa uang tunai. Penentuan besarnya harga dasar bangunan dan klasifikasinya ditetapkan dalam SK Walikota Padang Nomor 118.45.06.70. 2001 tentang Penetapan Harga Ganti Rugi Bangunan Masyarakat Yang Terkena Proyek Pembangunan Pemerintah Dalam Kota Padang, diuraikan dalam Tabel 1 ' berikut: ${ }^{15}$

Tabel 1. Penetapan Harga Ganti Rugi Bangunan Masyarakat yangTerkena Proyek Pembangunan Pemerintah dalam Kota Padang

\begin{tabular}{llcc}
\hline No. & Nama Bangunan & Satuan & Jumlah Harga (Rp) \\
\hline 1 & Permanen A & M2 & $890.500,00$ \\
2 & Permanen B & M2 & $875.150,00$ \\
3 & Permanen C & M2 & $745.800,00$ \\
4 & Semi Permanen A & M2 & $690.010,00$ \\
5 & Semi Permanen B & M2 & $650.525,70$ \\
6 & Kayu A & M2 & $876.345,37$ \\
7 & Kayu B & M2 & $750.033,35$ \\
8 & Darurat A & M2 & $216,337,30$ \\
9 & Darurat B & M2 & $200.308,55$ \\
\hline
\end{tabular}

Wawancara dengan Ketua KAN Kuranji tanggal 18 April 2012.

Iswandi, 2011, Pemberian Ganti Kerugian Dalam Pengadaan Tanah Untuk Pembangunan Jalur Evakuasi Tsunami Alai-by Pass di Kota Padang (Studi Kasus Pelebaran Jalan Alai-by Pass), Penulisan Hukum, Bagian Hukum Administrasi Negara, Universitas Andalas, Padang, hlm.. 41-57.

14 Wawancara dengan Yoga, Pejabat Pemkot Padang, dilakukan tanggal 18 April 2012. 
10 Teras Tertutup Permanen A

11 Teras Tertutup Permanen B

12 Teras Tertutup Semi Permanen A

13 Teras Tertutup Semi Permanen B

14 Teras Kayu A

15 Teras Kayu B

16 Teras Tertutup Kayu

17 Teras Tertutup Biasa

18 Teras Tertutup Darurat

19 Teras Tertutup Biasa

20 Bangunan Bertingkat A

21 Bangunan Bertingkat B

22 Bangunan Bertingkat $C$

23 Selasar

24 Loneng

25 Pondasi Tg. 1.00 M1

26 Pondasi Tg. 1.50 M1

27 Pondasi Tg. 2.00 M1

28 Sumur $80 \mathrm{Cm}$

29 WC

30 Bak Air

31 Bak Mandi Keramik

32 Septic tank

33 Tungku Keramik

34 Gorong-gorong 80 inci

35 Pagar Besi Beton

36 Pagar Hollobrick/ Bata 1.5 M

37 Sumur Bor

38 Pagar Samping Beton

39 Duiker A

40 Duiker B

41 Duiker $\mathrm{C}$

\begin{tabular}{cr} 
M2 & $9.325 .070,00$ \\
M2 & $875.500,00$ \\
M2 & $207.675,00$ \\
M2 & $245.500,00$ \\
M2 & $402.000,00$ \\
M2 & $245.000,00$ \\
M2 & 115.500 .00 \\
M2 & $245.000,00$ \\
M2 & $115.578,00$ \\
M2 & $167.768,00$ \\
M2 & $1.978 .000,00$ \\
M2 & $1.897 .000,00$ \\
M2 & $1.756 .732,00$ \\
M2 & $56.875,00$ \\
M2 & $75.000,00$ \\
M2 & $87.000,00$ \\
M2 & $94.000,00$ \\
M2 & $175.000,00$ \\
Cincin & $302.000,00$ \\
Unit & $875.000,00$ \\
Unit & $223.500,00$ \\
Unit & $450.000,00$ \\
Unit & $758.000,00$ \\
Unit & $950.000,00$ \\
Buah & $267.765,00$ \\
M1 & $256.069,40$ \\
M1 & $1.975 .000,00$ \\
Unit & $152.248,00$ \\
M1 & $403.000,00$ \\
M2 & $302.000,00$ \\
M2 & \\
M2 & 4 \\
\hline
\end{tabular}

Sumber: Lampiran SK Walikota Padang Nomor 118.45.06.70. 2001 tentang Penetapan Harga Ganti Rugi Bangunan Masyarakat yang Terkena Proyek Pembangunan Pemerintah dalam Kota Padang.

Tabel 2. Penetapan Dasar Ganti Rugi Tanaman Terkena Kegiatan Pembangunan untuk Kepentingan Umum dalam Kota Padang

\begin{tabular}{llccll}
\hline No. $\begin{array}{l}\text { Jenis } \\
\text { Tanaman }\end{array}$ & $\begin{array}{l}\text { Klasifikasi } \\
\text { Tanaman }\end{array}$ & $\begin{array}{c}\text { Satuan } \\
\text { Batang } \\
\text { Rumpun }\end{array}$ & $\begin{array}{c}\text { Harga } \\
\text { Satuan } \\
\text { (Rp) }\end{array}$ & Keterangan \\
\hline 1. & Nangka & $\mathrm{SB}$ & $\mathrm{Btg}$ & 40.000 & Sudah berbuah \\
& & $\mathrm{BB}$ & $\mathrm{Btg}$ & 15.000 & Belum berbuah \\
2. & Durian & $\mathrm{K}$ & $\mathrm{Btg}$ & 5.000 & Kecil \\
& & $\mathrm{BB}$ & $\mathrm{Btg}$ & 105.000 & Sudah berbuah \\
& & $\mathrm{B}$ & $\mathrm{Btg}$ & 50.000 & Belum berbuah \\
3. & Mangga & $\mathrm{SB}$ & $\mathrm{Btg}$ & 10.000 & Kecil \\
& & $\mathrm{BB}$ & $\mathrm{Btg}$ & 65.000 & Sudah berbuah \\
& & $\mathrm{K}$ & $\mathrm{Btg}$ & 35.000 & Belum berbuah \\
4. & Pisang & $\mathrm{SB}$ & $\mathrm{Btg}$ & 10.000 & Kecil \\
& & $\mathrm{BB}$ & $\mathrm{Btg}$ & 5.000 & Sudah berbuah \\
& & $\mathrm{K}$ & $\mathrm{Btg}$ & 2.000 & Belum berbuah \\
5. & Pepaya & $\mathrm{SB}$ & $\mathrm{Btg}$ & 10.000 & Kecil \\
& & $\mathrm{BB}$ & $\mathrm{Btg}$ & 5.000 & Sudah berbuah \\
& & & & & Belum berbuah \\
\hline
\end{tabular}

15 SK Walikota Padang Nomor 118.45.06.70. 2001 tentang Penetapan Harga Ganti Rugi Bangunan Masyarakat yang Terkena Proyek Pembangunan Pemerintah dalam Kota Padang. 


\begin{tabular}{|c|c|c|c|c|c|}
\hline & & $\mathrm{K}$ & Btg & 2.000 & Kecil \\
\hline \multirow[t]{3}{*}{6.} & Jambu air & SB & Btg & 30.000 & Sudah berbuah \\
\hline & & BB & Btg & 12.000 & Belum berbuah \\
\hline & & K & Btg & 3.000 & Kecil \\
\hline \multirow[t]{3}{*}{7.} & Rambutan & SB & Btg & 90.000 & Sudah berbuah \\
\hline & & BB & Btg & 35.000 & Belum berbuah \\
\hline & Btg & 7.500 & Kecil & & \\
\hline \multirow[t]{3}{*}{8.} & Jengkol & SB & Btg & 70.000 & Sudah berbuah \\
\hline & & BB & Btg & 30.000 & Belum berbuah \\
\hline & & K & Btg & 5.000 & Kecil \\
\hline \multirow[t]{3}{*}{9.} & Petai & SB & Btg & 75.000 & Sudah berbuah \\
\hline & & BB & Btg & 30.000 & Belum berbuah \\
\hline & & $\mathrm{K}$ & Btg & 7.500 & Kecil \\
\hline \multirow[t]{3}{*}{10.} & Jeruk & SB & Btg & 30.000 & Sudah berbuah \\
\hline & & BB & Btg & 15.000 & Belum berbuah \\
\hline & & $\mathrm{K}$ & Btg & 7.500 & Kecil \\
\hline
\end{tabular}

Sumber: SK Walikota Padang Nomor 188.45.06.85. Tahun 1999 tentang Penetapan Dasar

\begin{tabular}{|c|c|}
\hline 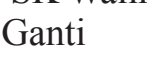 & Rugi \\
\hline gunan & untuk \\
\hline
\end{tabular}

(2) Tahap Kedua pada Tahun 20062007

Pengadaan tanah pada tahun 2002 sempat tertunda karena pelepasan hak atas tanah masyarakat yang terkena proyek pelebaran jalan Alai-by Pass tidak terlaksana secara keseluruhan karena masih ada beberapa masyarakat yang belum mau melepaskan tanahnya. Penyebab utama tidak maunya sebagian masyarakat untuk melepaskan hak atas tanahnya karena menganggap nilai ganti kerugian yang ditetapkan dalam SK Walikota Padang Nomor 118.45.06.70. 2001 dan SK Walikota Padang Nomor 188.45.06.85. 1999 tidak sesuai dengan kondisi pada saat itu. Pada tahun 2006, Walikota Padang mengeluarkan SK Nomor 01 Tahun 2005 Tentang Penetapan Harga Ganti Rugi Bangunan Masyarakat Yang Terkena Proyek Pembangunan Pemerintah Dalam Kota Padang, menggantikan dan mencabut SK Walikota Padang sebelumnya, yaitu SK Walikota Padang 118.45.06.70. 2001 dan juga kemudian mengeluarkan SK Walikota Padang Nomor 204 Tahun 2006 Tentang Harga Dasar Ganti Rugi Tanaman Terkena Kegiatan Pembangunan Untuk Kepentingan Umum Dalam Kota Padang, yang mengganti dan mencabut SK Walikota Padang Nomor 188.45.06.85. 1999.

Tabel 3. Penetapan Harga Ganti Rugi Bangunan Masyarakat yang Terkena Proyek Pembangunan Pemerintah dalam Kota Padang

\begin{tabular}{llcc}
\hline No. & Nama Bangunan & Satuan & Jumlah Harga (Rp) \\
\hline 1 & Permanen A & M2 & $1.109 .500,00$ \\
2 & Permanen B & M2 & $9.890 .150,00$ \\
3 & Permanen C & M2 & $902.800,00$ \\
4 & Semi Permanen A & M2 & $890.010,00$ \\
5 & Semi Permanen B & M2 & $870.525,70$ \\
6 & Kayu A & M2 & $806.345,37$ \\
7 & Kayu B & M2 & $375,337,35$ \\
8 & Darurat A & M2 & $332.308,55$ \\
9 & Darurat B & M2 & $1.085 .070,00$ \\
10 & Teras Tertutup Permanen A & M2 & $1.021 .500,00$ \\
11 & Teras Tertutup Permanen B & & \\
\hline
\end{tabular}




\begin{tabular}{|c|c|c|c|}
\hline 12 & Teras Tertutup Semi Permanen A & M2 & $333.675,00$ \\
\hline 13 & Teras Tertutup Semi Permanen B & M2 & $305.500,00$ \\
\hline 14 & Teras Kayu A & M2 & $515.000,00$ \\
\hline 15 & Teras Kayu B & M2 & $375.000,00$ \\
\hline 16 & Teras Tertutup Kayu & M2 & 195.500 .00 \\
\hline 17 & Teras Tertutup Biasa & M2 & $385.500,00$ \\
\hline 18 & Teras Tertutup Darurat & M2 & $195.500,00$ \\
\hline 19 & Teras Tertutup Biasa & M2 & $202.500,00$ \\
\hline 20 & Bangunan Bertingkat A & M2 & $2.235 .000,00$ \\
\hline 21 & Bangunan Bertingkat B & M2 & $1.900 .000,00$ \\
\hline 22 & Bangunan Bertingkat $\mathrm{C}$ & M2 & $1.876 .732,00$ \\
\hline 23 & Selasar & M2 & $60.876,00$ \\
\hline 24 & Loneng & M2 & $85.500,00$ \\
\hline 25 & Pondasi Tg. 1.00 M1 & M2 & $102.500,00$ \\
\hline 26 & Pondasi Tg. $1.50 \mathrm{M} 1$ & M2 & $105.789,00$ \\
\hline 27 & Pondasi Tg. $2.00 \mathrm{M} 1$ & M2 & $200.345,00$ \\
\hline 28 & Sumur $80 \mathrm{Cm}$ & Cincin & $460.345,00$ \\
\hline 29 & WC & Unit & $9.756 .768,00$ \\
\hline 30 & Bak Air & Unit & $302.578,00$ \\
\hline 31 & Bak Mandi Keramik & Unit & $570.678,00$ \\
\hline 32 & Septic tank & Unit & $9.756 .768,00$ \\
\hline 33 & Tungku Keramik & Unit & $570.679,00$ \\
\hline 34 & Gorong-gorong 80 inci & Buah & $143.546,00$ \\
\hline 35 & Pagar Besi Beton & M1 & 402.765 .00 \\
\hline 36 & Pagar Hollobrick/ Bata 1.5 M & M1 & $450.069,40$ \\
\hline 37 & Sumur Bor & Unit & $2.435 .765,00$ \\
\hline 38 & Pagar Samping Beton & M1 & $457.357,00$ \\
\hline 39 & Duiker A & M2 & $102.546,00$ \\
\hline 40 & Duiker B & M2 & $650.000,00$ \\
\hline 41 & Duiker C & M2 & $470.000,00$ \\
\hline
\end{tabular}

Tabel 4. Penetapan Dasar Ganti Rugi Tanaman Terkena Kegiatan Pembangunan untuk Kepentingan Umum dalam Kota Padang

\begin{tabular}{llllll}
\hline No. & JenisTanaman & $\begin{array}{l}\text { Klasifikasi } \\
\text { Tanaman }\end{array}$ & $\begin{array}{l}\text { Satuan } \\
\text { Batang } \\
\text { Rumpun }\end{array}$ & $\begin{array}{l}\text { Harga } \\
\text { Satuan } \\
\text { (Rp) }\end{array}$ & Keterangan \\
\hline 1. & Nangka & SB & Btg & 50.000 & Sudah berbuah \\
& & BB & Btg & 20.000 & Belum berbuah \\
2. & Durian & SB & Btg & 10.000 & Kecil \\
& & Btg & 150.000 & Sudah berbuah \\
& & BB & Btg & 75.000 & Belum berbuah \\
3. & Mangga & SB & Btg & 20.000 & Kecil \\
& & BB & Btg & 100.000 & Sudah berbuah \\
& & K & Btg & 10.000 & Belum berbuah \\
4. & Pisang & SB & Btg & 15.000 & Kecil \\
& & BB & Btg & 7.000 & Sudah berbuah \\
& & K & Btg & 3.000 & Kecil berbuah \\
5. & Pepaya & SB & Btg & 12.000 & Sudah berbuah \\
& & BB & Btg & 7.000 & Belum berbuah \\
& & K & Btg & 3.000 & Kecil \\
6. & Jambu air & SB & Btg & 45.000 & Sudah berbuah \\
\hline
\end{tabular}




\begin{tabular}{|c|c|c|c|c|c|}
\hline \multirow{4}{*}{7.} & & $\mathrm{BB}$ & Btg & 20.000 & Belum berbuah \\
\hline & \multirow{3}{*}{ Rambutan } & $\mathrm{K}$ & Btg & 5.000 & Kecil \\
\hline & & SB & Btg & 125.000 & Sudah berbuah \\
\hline & & $\mathrm{BB}$ & Btg & 55.000 & Belum berbuah \\
\hline \multirow{4}{*}{8.} & \multirow{4}{*}{ Jengkol } & $\mathrm{K}$ & Btg & 15.000 & Kecil \\
\hline & & SB & Btg & 100.000 & Sudah berbuah \\
\hline & & $\mathrm{BB}$ & Btg & 50.000 & Belum berbuah \\
\hline & & $\mathrm{K}$ & Btg & 10.000 & Kecil \\
\hline \multirow[t]{3}{*}{9.} & \multirow[t]{3}{*}{ Petai } & SB & Btg & 100.000 & Sudah berbuah \\
\hline & & BB & Btg & 50.000 & Belum berbuah \\
\hline & & $\mathrm{K}$ & Btg & 10.000 & Kecil \\
\hline \multirow[t]{3}{*}{10.} & \multirow[t]{3}{*}{ Jeruk } & SB & Btg & 50.000 & Sudah berbuah \\
\hline & & $\mathrm{BB}$ & Btg & 25.000 & Belum berbuah \\
\hline & & $\mathrm{K}$ & Btg & 15.000 & Kecil \\
\hline
\end{tabular}

Sumber: SK Walikota Padang Nomor 204 Tahun 2006 tentang Penetapan Dasar Ganti Rugi Tanaman Terkena Kegiatan Pembangunan Untuk Kepentingan Umum Dalam Kota Padang.

(3) Tahap Ketiga pada Tahun 2010

Pengadaan tanah lanjutan untuk pelebaran jalan Alai-by Pass setelah dikeluarkannya SK Walikota Padang Nomor 01 Tahun 2005 dan SK Walikota Padang Nomor 204 Tahun 2006 juga tidak berjalan lancar karena masih terdapat beberapa anggota masyarakat yang tidak mau melepaskan hak atas tanahnya beserta bangunan dan tanaman yang ada di atasnya. Ini disebabkan karena masyarakat masih menganggap harga dasar untuk ganti kerugian terhadap bangunan dan tanaman mereka belum cocok dengan harga dasar pada saat itu. Pelaksanaan pengadaan tanah pada tahun 2005 sampai tahun 2006 kembali terhenti dari tahun 2007 sampai dengan tahun 2009. ${ }^{16}$ Dengan diberikannya ganti kerugian terhadap bangunan dan benda-benda yang ada diatas tanah berupa uang, maka kondisi seperti ini mengubah mind set semua stake holders untuk berpikir tentang nilai-nilai nominal yang berkaitan dengan uang yang mengakibatkan timbulnya konflik kepentingan diantara mereka. ${ }^{17}$

\section{c) Faktor Eksternal}

Munculnya konflik juga dipengaruhi oleh faktor eksternal yang terdiri atas pihak-pihak di luar para pihak yang terlibat langsung dalam pengadaan tanah ini. Pihak ke tiga tersebut adalah orang-orang yang sengaja memancing di air keruh. Person pihak ke tiga memang tidak mudah terdeteksi tetapi dampaknya cukup nyata. Responden yang diwawancarai juga tidak bersedia menyebutkan secara spesifik siapa orangnya. ${ }^{18}$ Narasumber yang tidak bersedia disebut identitasnya mengatakan ada keterlibatan LSM, dengan alasan konflik ini merupakan konflik konstruktif dalam arti supaya tercapai ganti kerugian yang adil dan layak sesuai peraturan perundangan yang berlaku, bahwa seharusnya bukan "ganti kerugian" akan tetapi "recognitie" yang memperhitungkan juga nilai tanahnya, tidak hanya tanaman dan bangunan saja. Lebih lanjut Warner dalam LR.Wibowo, menyatakan bahwa: Dalam kerangka non kekerasan, konflik sering dipandang sebagai kekuatan untuk terjadinya perubahan sosial yang positif. ${ }^{19}$ Secara positif konflik juga membantu pem-

6 Wawancara dengan Yoga, Pejabat Pemkot Padang tanggal 8 April 2012.

17 Wawancara dengan Ketua KAN dan beberapa ketua adat Kuranji tanggal 8 April 2012. 
bentukan struktur masyarakat dengan memberi sumbangan pada ketahanan dan adaptasi kelompok. ${ }^{20}$

2. Upaya Para Pihak dalam Mengatasi Konflik

Menurut Alidinar Nurdin, untuk menyelesaikan konflik perlu dilakukan "Pemetaan Konflik" agar: (1) lebih memahami konflik dengan baik; (2) melihat hubungan di antara berbagai pihak dengan jelas; (3) menjelaskan di mana letak kekuasaan; (4) memeriksa keseimbangan masing-masing kegiatan atau reaksi; (5) mengidentifikasi mulainya intervensi atau tindakan; (6) mengevaluasi apa yang dilakukan berbagai pihak. ${ }^{21}$ Menurut Simon Fisher, dalam mengelola konflik perlu diupayakan dialog antara para pihak yang berkonflik, sehingga tidak ditentukan secara sepihak. ${ }^{22}$
Untuk mengatasi konflik ini, maka Walikota Padang kembali mengeluarkan SK Walikota Padang Nomor 3 Tahun 2010. Dengan dikeluarkannya dua SK Walikota Padang terbaru ini diharapkan masyarakat mau melepaskan hak atas tanahnya setelah memperoleh ganti kerugian untuk tiap bangunan dan tanaman yang dimiliki masyarakat. 2 (dua) SK Walikota Padang yang baru ini merubah harga dasar per meter tiap bangunan dan per batang atau rumpun tanaman. Dengan begitu diharapkan tidak ada lagi diprotes masyarakat terhadap penentuan harga dasar per meter bangunan dan per batang atau rumpun tanaman yang dianggap tidak sesuai lagi dengan harga dasar saat ini. Mengenai besarnya ganti kerugian untuk harga dasar per meter bangunan berdasarkan SK Walikota Padang Nomor 5 Tahun 2010 dapat dirincikan dalam tabel berikut:

Tabel 5. Penetapan Harga Ganti Rugi Bangunan Masyarakat yang Terkena Proyek Pembangunan Pemerintah dalam Kota Padang

\begin{tabular}{llcr}
\hline No. & Nama Bangunan & Satuan & Jumlah Harga (Rp) \\
\hline 1 & Permanen A & M2 & $2.050 .400,00$ \\
2 & Permanen B & M2 & $1.922 .250,00$ \\
3 & Permanen C & M2 & $1.602 .000,00$ \\
4 & Semi Permanen A & M2 & $1.225 .070,00$ \\
5 & Semi Permanen B & M2 & $1.137 .500,00$ \\
6 & Kayu A & M2 & $1.048 .345,37$ \\
7 & Kayu B & M2 & $909.033,35$ \\
8 & Darurat A & M2 & $416,337,30$ \\
9 & Darurat B & M2 & $374.308,55$ \\
10 & Teras Tertutup Permanen A & M2 & $1.225 .070,00$ \\
11 & Teras Tertutup Permanen B & M2 & $1.137 .500,00$ \\
12 & Teras Tertutup Semi Permanen A & M2 & $389.675,00$ \\
13 & Teras Tertutup Semi Permanen B & M2 & $357.500,00$ \\
14 & Teras Kayu A & M2 & $595.000,00$ \\
15 & Teras Kayu B & M2 & $425.000,00$ \\
16 & Teras Tertutup Kayu & M2 & 212.500 .00 \\
17 & Teras Tertutup Biasa & M2 & $425.000,00$ \\
18 & Teras Tertutup Darurat & M2 & $212.500,00$ \\
19 & Teras Tertutup Biasa & M2 & $250.000,00$ \\
20 & Bangunan Bertingkat A & M2 & $2.982 .000,00$ \\
21 & Bangunan Bertingkat B & M2 & $2.130 .000,00$ \\
22 & Bangunan Bertingkat C & M2 & $2.063 .732,00$ \\
23 & Selasar & M2 & $70.875,00$ \\
24 & Loneng & M2 & $100.000,00$ \\
25 & Pondasi Tg. 1.00 M1 & M2 & $150.000,00$ \\
26 & Pondasi Tg. 1.50 M1 & M2 & $175.000,00$ \\
\hline
\end{tabular}

8 Wawancara dengan Bapak Mandani, Pantia Pembantu dari masyarakat tanggal 10 April 2012.

19 L.R. Wibowo, C.Woro Murdiati Runggandini, Subarudi, 2008, Konflik Sumber Daya Hutan dan Reforma Agraria, Kapitalisme Mengepung Desa, Alfamedia, Yogyakarta, hlm. 54.

20 M.M. Paloma, 1979, Sosiologi Kontemporer, Rajawali Press, Jakarta, hlm. 121

21 Alidinar Nurdin, 2007, Resolusi Konflik Tanah Ulayat di Minangkabau Propinsi Sumatera Barat, Studi Kasus Tujuh Nagari Konflik di Propinsi Sumatera Barat, Disertasi, Program Pasca Sarjana Universitas Andalas, Padang, hlm. 62.

22 Simon Fisher, 2000, Working with Conflict, Skills and Strategies for Action, RTC, Birmingham, UK, hlm. 5. 


$\begin{array}{lllr}27 & \text { Pondasi Tg. 2.00 M1 } & \text { M2 } & 250.000,00 \\ 28 & \text { Sumur 80 Cm } & \text { Cincin } & 510.000,00 \\ 29 & \text { WC } & \text { Unit } & 1.050 .000,00 \\ 30 & \text { Bak Air } & \text { Unit } & 437.500,00 \\ 31 & \text { Bak Mandi Keramik } & \text { Unit } & 700.000,00 \\ 32 & \text { Septic tank } & \text { Unit } & 1.050 .000,00 \\ 33 & \text { Tungku Keramik } & \text { Unit } & 700.000,00 \\ 34 & \text { Gorong-gorong } 80 \text { inci } & \text { Buah } & 170.000,00 \\ 35 & \text { Pagar Besi Beton } & \text { M1 } & 517.765 .00 \\ 36 & \text { Pagar Hollobrick/ Bata 1.5 M } & \text { M1 } & 581.069,40 \\ 37 & \text { Sumur Bor } & \text { Unit } & 2.856 .000,00 \\ 38 & \text { Pagar Samping Beton } & \text { M1 } & 581.000,00 \\ 39 & \text { Duiker A } & \text { M2 } & 152.248,00 \\ 40 & \text { Duiker B } & \text { M2 } & 850.000,00 \\ 41 & \text { Duiker C } & \text { M2 } & 680.000,00\end{array}$

Sumber: Surat keputusan Walikota Padang Nomor 5 Tahun 2010 tentang Penetapan Harga Ganti Rugi Bangunan Masyarakat yang Terkena Proyek Pembangunan Pemerintah dalam Kota Padang.

Tabel 6. Penetapan Dasar Ganti Rugi Tanaman Terkena Kegiatan Pembangunan untuk Kepentingan Umum dalam Kota Padang

\begin{tabular}{|c|c|c|c|c|c|}
\hline No. & $\begin{array}{l}\text { Jenis } \\
\text { Tanaman }\end{array}$ & $\begin{array}{c}\text { Klasifikasi } \\
\text { Tanaman }\end{array}$ & $\begin{array}{l}\text { Satuan } \\
\text { Batang } \\
\text { Rumpun }\end{array}$ & $\begin{array}{l}\text { Harga } \\
\text { Satuan } \\
\text { (Rp) }\end{array}$ & Keterangan \\
\hline \multirow[t]{3}{*}{1} & \multirow[t]{3}{*}{ Nangka } & SB & Btg & 75.000 & Sudah berbuah \\
\hline & & $\mathrm{BB}$ & Btg & 35.000 & Belum berbuah \\
\hline & & K & Btg & 20.000 & Kecil \\
\hline \multirow[t]{3}{*}{2} & \multirow[t]{3}{*}{ Durian } & SB & Btg & 250.000 & Sudah berbuah \\
\hline & & $\mathrm{BB}$ & Btg & 100.000 & Belum berbuah \\
\hline & & $\mathrm{K}$ & Btg & 35.000 & Kecil \\
\hline \multirow[t]{3}{*}{3} & \multirow[t]{3}{*}{ Mangga } & SB & Btg & 150.000 & Sudah berbuah \\
\hline & & BB & Btg & 75.000 & Belum berbuah \\
\hline & & $\mathrm{K}$ & Btg & 20.000 & Kecil \\
\hline \multirow[t]{3}{*}{4} & \multirow[t]{3}{*}{ Pisang } & SB & Btg & 20.000 & Sudah berbuah \\
\hline & & BB & Btg & 10.000 & Belum berbuah \\
\hline & & $\mathrm{K}$ & Btg & 5.000 & Kecil \\
\hline \multirow[t]{3}{*}{5} & \multirow[t]{3}{*}{ Pepaya } & SB & Btg & 15.000 & Sudah berbuah \\
\hline & & $\mathrm{BB}$ & Btg & 10.000 & Belum berbuah \\
\hline & & $\mathrm{K}$ & Btg & 5.000 & Kecil \\
\hline \multirow[t]{3}{*}{6} & \multirow{3}{*}{ Jambu air } & SB & Btg & 60.000 & Sudah berbuah \\
\hline & & BB & Btg & 30.000 & Belum berbuah \\
\hline & & $\mathrm{K}$ & Btg & 10.000 & Kecil \\
\hline \multirow[t]{3}{*}{7} & \multirow{3}{*}{ Rambutan } & SB & Btg & 150.000 & Sudah berbuah \\
\hline & & BB & Btg & 75.000 & Belum berbuah \\
\hline & & $\mathrm{K}$ & Btg & 20.000 & Kecil \\
\hline \multirow[t]{3}{*}{8} & \multirow{3}{*}{ Jengkol } & SB & Btg & 150.000 & Sudah berbuah \\
\hline & & $\mathrm{BB}$ & Btg & 75.000 & Belum berbuah \\
\hline & & $\mathrm{K}$ & Btg & 20.000 & Kecil \\
\hline \multirow[t]{3}{*}{9} & \multirow{3}{*}{ Petai } & SB & Btg & 150.000 & Sudah berbuah \\
\hline & & BB & Btg & 75.000 & Belum berbuah \\
\hline & & $\mathrm{K}$ & Btg & 20.000 & Kecil \\
\hline \multirow[t]{3}{*}{10} & \multirow[t]{3}{*}{ Jeruk } & SB & Btg & 75.000 & Sudah berbuah \\
\hline & & BB & Btg & 35.000 & Belum berbuah \\
\hline & & $\mathrm{K}$ & Btg & 20.000 & Kecil \\
\hline
\end{tabular}

Sumber: SK Walikota Padang Nomor 3 Tahun 2010 tentang Penetapan Dasar Ganti Rugi Tanaman Terkena Kegiatan Pembangunan Untuk Kepentingan Umum Dalam Kota Padang. 
Menurut Ari Dwipayana, penyelesaian konflik dapat dilakukan dengan upayaupaya: (1) manifestasi dialog; (2) negosiasi; (3) mediasi; (4) arbitrasi. ${ }^{23}$ Sedangkan James A. Schelenberg menambahkan adjudication (penyelesaian konflik dengan menggunakan kekuatan Negara. ${ }^{24}$ Konflik tersebut di atas berlangsung sampai bertahun-tahun tetapi belum mencapai eskalasi ke pengadilan. Upaya penyelesaian konflik sudah dilakukan para pihak melalui jalur non litigasi yaitu dengan cara bermusyawarah. Berdasarkan hasil musyawarah yang berlangsung berkalikali dan beberapa kali berhenti pelaksanaannya, dicapai kesepakatan bahwa Pemkot Padang hanya akan memberikan ganti kerugian kepada masyarakat dalam bentuk uang tunai terhadap nilai bangunan dan tanaman yang terkena proyek pelebaran jalan Alai-By Pass. Terhadap tanah masyarakat, Pemkot Padang tidak memberikan ganti kerugian. Dapat disimpulkan, pemberian ganti kerugian kepada masyarakat yang tanahnya terkena proyek pelebaran jalan Alai-By Pass hanya sebatas pada bangunan dan tanaman yang terdapat di atas tanah masyarakat tersebut. ${ }^{25}$

\section{Kesimpulan}

Faktor- faktor yang menyebabkan timbulnya konflik dalam pengadaan tanah untuk pembangunan jalur evakuasi tsunami Alai-by pass di Padang: Pertama, faktor internal dari masyarakat: (a) subyek hak yang tidak jelas, sebagai akibat dari masih banyaknya tanah-tanah yang belum bersertipikat dan status kepemilikan tanah yang masih komunal; (b) obyek ganti kerugian tidak termasuk tanah tetapi hanya untuk tanaman dan bangunan sehingga hanya pihak anggota kaum yang mempunyai bangunan dan tanaman saja yang mendapatkan ganti kerugian; (c) jumlah ganti kerugian yang diterima oleh setiap anggota kaum berbeda tergantung pada sedikit atau banyaknya tanaman dan bangunan yang terkena jalur pengadaan tanah untuk pembangunan sehingga ada kecemburuan dari para anggota kaum; (d) sifat masyarakat yang relatif tidak disiplin, tingkat pendidikan yang rendah dan temperamental, sehingga mengakibatkan musyawarah yang dilaksanakan di Kantor KAN tidak dapat berjalan lancar. Tidak disiplin ini misalnya tidak semua undangan dapat hadir pada setiap musyawarah. Sifat temperamental juga menyebabkan sulitnya tercapai kata sepakat, sehingga perlu musyawarah berkali-kali.

Kedua, faktor internal dari Pemerintah: (a) Ketidakmampuan Pemerintah yang diwakili oleh Panitia Pengadaan Tanah dalam mendekati masyarakat karena tidak paham budaya masyarakat setempat sehingga tidak memahami manajemen konflik yang mengakibatkan konflik berkepanjangan; (b) Penentuan ganti kerugian yang terkesan sepihak yang dibuktikan dari adanya SK Walikota Padang tentang penetapan harga ganti-rugi bangunan dan tanaman dalam setiap tahapan pengadaan tanah. Ketiga, faktor eksternal yakni Munculnya konflik juga dipengaruhi oleh faktor eksternal yang terdiri atas pihak-pihak di luar para pihak yang terlibat langsung dalam pengadaan tanah ini. Pihak ke tiga tersebut adalah orang-orang yang sengaja memancing di air keruh. Person pihak ke tiga memang tidak mudah terdeteksi tetapi dampaknya cukup nyata. Responden yang diwawancarai juga tidak bersedia menyebutkan secara spesifik siapa orangnya. Narasumber yang tidak bersedia disebut identitasnya mengatakan ada keterlibatan LSM, dengan alasan konflik ini merupakan konflik konstruktif dalam arti supaya tercapai ganti kerugian yang adil dan layak sesuai naman peraturan perundangan yang berlaku, bahwa seharusnya bukan "ganti kerugian" akan tetapi "recognitie" yang memperhitungkan juga nilai tanahnya, tidak hanya tanaman dan bangunan saja. Upaya yang ditempuh oleh kedua belah pihak untuk mengatasi konflik yakni proses penyelesaian konflik tersebut dilakukan secara non

\footnotetext{
23 Ari Dwipayana, 2004, Mengelola Konflik Batas Wilayah, Panduan Bagi Prajuru Desa Pakraman, Uluiangkep Press, Pengosekan, Ubud, Gianyar, Bali, hlm. 43.

24 James A, Schellenberg, 1996, Conflict Resolution Theory, Research, and Practice, University of New York Press, USA, hlm. 15.

25 Wawancara dengan Ketua KAN dan beberapa ketua adat, tanggal 18 April 2012.
} 
litigasi yaitu penyelesaian konflik di luar pengadilan. Sesuai dengan asas yang ada dalam hukum adat bahwa segala sesuatunya sebaiknya diselesaikan secara musyawarah mufakat, maka musyawarah dilakukan untuk mencapai kesepakatan atas tuntutan masyarakat terhadap Pemerintah. Adapun tahap yang dilalui dalam penyelesaian konflik tersebut ada dua tahap yaitu: tahap pertama, berupa musyawarah yang dilakukan oleh masyarakat dengan panitia pengadaan tanah beserta panitia pendamping dari masyarakat. Pada tahap ini dicapai yang pertama: kesepakatan mengenai, bahwa tanah tidak diberikan ganti kerugian tetapi yang diberikan ganti kerugian hanya terhadap bangunan dan tanaman kesepakatan ini dituangkan nota kesepakatan. Adapun tahap kedua adalah musyawarah untuk menentukan pihak yang menerima ganti kerugian bangunan dan tanaman yang meliputi anggota kaum yang memiliki bangunan dan tanaman dan melaksanakan pemberian ganti kerugian yang dilaksanakan dalam kurun waktu dari tahun 2003 sampai dengan 2010

Merujuk pada penjabaran di atas maka saran yang dapat diberikan antara lan adalah: Pemerintah harus melibatkan Kerapatan Adat Nagari (KAN) terlebih dahulu, KAN merupakan wadah berkumpulnya dan bermusyawarahnya para Pemangku Adat, untuk mencari sayak nan landai dan aie nan janiah (win-win solution) dalam rangka menyelesaikan masalah (KUSUIK) dalam masyarakat. Pemerintah bersama KAN melakukan pendekatan kepada Ninik Mamak Kepala Waris dari kaum/suku dan para kemenakan yang terkait dengan obyek tersebut serta tidak boleh ada perwakilan. Seandainya obyek tersebut menyangkut dengan tanah Perumahan maka Pemerintah bersama KAN dan Ninik Mamak Kepala Waris membicarakan dengan pemilik rumah sehingga tidak ada yang merasa ditinggalkan.

\section{DAFTAR PUSTAKA}

A. Buku

Affandi, Hakimul Ikhwan, 2004, Akar Konflik Sepanjang Zaman, Elaborasi Pemikiran Ibnu Khaldum, Pustaka Pelajar, Yogyakarta.

Dwipayana, Ari, 2004, Mengelola Konflik Batas Wilayah, Panduan Bagi Prajuru Desa Pakraman, Uluiangkep Press, Pengosekan, Ubud, Gianyar, Bali.

Fisher, Simon, 2000, Working with Conflict, Skills and Strategies for Action, RTC, Birmingham, UK.

Paloma, M.M., 1979, Sosiologi Kontemporer, Rajawali Press, Jakarta.

Rohmad, Abu, 2008, Paradigma Resolusi Konflik Agraria, Walisongo Press, Semarang.

Schellenberg, James A., 1996, Conflict Resolution Theory, Research, and Practice, University of New York Press, USA.

Sudiyat, Iman, 1981, Hukum Adat Sketsa Asas, Liberty, Yogyakarta.

Sumardjono, Maria S.W., 2007, Kebijakan Pertanahan, Antara Regulasi dan Implementasi, Penerbit Buku Kompas, Jakarta.
Walton, Richard E., 1969, Interpersonal PeaceMaking: Confrontation and Third-Party Consultation, Reading, Mass, AddisionWesley.

Warman, Kurnia, 2006, Ganggam Bauntuak Menjadi Hak Milik, Penyimpangan Konversi HAT di Sumatra Barat, Andalas University Press, Padang.

Wehr, P., 1979, Conflict Regulation, CO. Westview Press, Boulder.

Wibowo, L.R., C. Woro Murdiati Runggandini, Subarudi, 2008, Konflik Sumber Daya Hutan dan Reforma Agraria, Kapitalisme Mengepung Desa, Alfamedia, Yogyakarta.

\section{B. Tugas Akhir/Hasil Penelitian}

Iswandi, 2011, Pemberian Ganti Kerugian Dalam Pengadaan Tanah Untuk Pembangunan Jalur Evakuasi Tsunami Alai-by Pass di Kota Padang (Studi Kasus Pelebaran Jalan Alaiby Pass), Penulisan Hukum, Bagian Hukum Administrasi Negara, Universitas Andalas, Padang. 
Nurdin, Alidinar, 2007, Resolusi Konflik Tanah Ulayat di Minangkabau Propinsi Sumatera Barat, Studi Kasus Tujuh Nagari Konflik di Propinsi Sumatera Barat, Disertasi, Program Pasca Sarjana Universitas Andalas, Padang.

\section{Artikel Internet}

Anonim, "Prinsip Keadilan adalah Kunci Soal Alay-by Pass", http://www.Padang Ekspress. co.id., diakses 1 Februari 2012.

Gayatri, Gusti Ayu, "Harus Perbanyak Simulasi
Tsunami”, $\quad$ http://padangekspres. co.id/?news=berita\&id=50299, diakses 28 Desember 2009.

\section{Peraturan Perundang-Undangan}

Surat Keputusan Walikota Padang Nomor 118.45. 06.70. 2001 tentang Penetapan Harga Ganti Rugi Bangunan Masyarakat yang Terkena Proyek Pembangunan Pemerintah dalam Kota Padang. 